\title{
Resources partitioning and different foraging behavior is the basis for the coexistence of Thrips hawaiiensis (Thysanoptera: Tripidae) and Elaeidobius kamerunicus (Coleoptera: Curculionidae) on oil palm (Elaeis guineensis Jacq) flower
}

\author{
Tjandra Anggraeni ${ }^{1}$, Suci Rahayu ${ }^{2}$, Intan Ahmad ${ }^{1}$, Rizkita Rachmi Esyanti ${ }^{1}$ and \\ Ramadhani Eka Putra ${ }^{1 *}$
}

\author{
${ }^{1}$ School of Life Sciences and Technology, Institut Teknologi Bandung, Bandung, Indonesia \\ ${ }^{2}$ Department of Biology Faculty of Mathematics and Natural Sciences Universitas Sumatera Utara, Medan, Indonesia
}

Accepted 3 July 2013

\begin{abstract}
Indonesia is considered as main producer of oil palm. Oil palm production depends on the pollination process of its flowers. Observation on Indonesian local oil palm (Elaeis guineensis) plantation showed the coexistence between introduced pollinator, Elaeidobius kamerunicus, and native pollinator Thrips hawaiiensis. In order to find the factors responsible for this coexistence, observation on $E$. kamerunicus and $T$. hawaiiensis response to volatile produced by flowers, response of insects to volatile, and daily activities was carried out. The result shows that estragol produced by male flowers and farnesol by female flowers highly influenced visitation of both $T$. hawaiiensis and $E$. kamerunicus. Furthermore, both species act differently on volatile releasing time indicating mechanism for coexistence. On the other hand, both species also forage in different time based on the average temperature and amount of sunlight. These experiments confirm that the coexistence between $E$. kamerunicus and $T$. hawaiiensis is maintained by plant and difference in foraging activities.
\end{abstract}

Key words: Elaeidobius kamerunicus, Elaeis guineensis, Thrips hawaiiensis, pollination, volatile compounds.

\section{INTRODUCTION}

It was only after the works of Syed in Cameroun and Malaysia in late 1970s and early 1980s respectively, scientists believed that in addition to wind-pollination, insects were needed for oil palm (Elaeis guineensis) pollination. In early studies, Syed found that Thrips hawaiiensis (Thysanoptera: Thripidae), a common flower inhabiting thrips in Asia and North America and also known as pest of banana, citrus, and figs, is an important pollinator of oil palm (Syed, 1979, 1980, 1981). This insect is commonly found in oil palm and considered as indigenous pollinator of oil palm in Malaysia (Syed et al., 1982) and Indonesian oil palm (Pardede, 1990a). Furthermore, the introduction of African oil palm weevil, Elaidobius kamerunicus, to Malaysia (Syed et al., 1982) and Indonesia in 1980s (Pardede, 1990b), significantly improved the productivity of oil palms in both countries.

Oil palm flower is monoecious and contains both female and male flowers on one tree. Flowers with different sex bloom at different times and are pollinated all year round (Henderson, 1986; Syed, 1979; Tandon et 
al., 2001). Fully developed flowers emitt strong aniseed smell (Aisagbonhi et al., 2004) which is actually estragole. This chemical is used by $E$. kamerunicus as olfactory cue to locate female flowers (Hussein et al., 1989, Adaigbe et al., 2011).

Although E. kamerunicus was successfully introduced into oil palm plantation and became the dominant species, in nature they seem to coexist with $T$. hawaiiensis. However, it is still not clear how the coexistence is maintained since both species utilize pollen as food and flower as their nesting area. Thus, we hypothesized that respond of $E$. kamerunicus and $T$. hawaiiensis to volatile compound emitted by flower along with their foraging activity may be responsible for maintaining the coexistence of both species inside oil palm flowers.

\section{MATERIALS AND METHODS}

\section{Collection and analysis of volatile compounds from flowers}

Prior to volatile collection, both male and female flowers were sealed in separated sterile nalophan (polymer casings) bag. Samples of volatile were collected from male and female flowers with different flowering stage. The flowering stages were divided into four stages based on the total number of flowers bloom $(25,50$, 75 , and $100 \%$ ). Volatile compounds were absorbed into a pore pact then extracted and analyzed by GC-MS to determine type and concentration of any volatile components released by sample (Grinson et al., 1999; Dufay et al., 2003).

The quality and quantity of volatile compounds of interest were assays by absorption-desorption method. Total sample area was 10 ha and during each sampling date (each month); volatile was collected from 10 plants. In total, 100 volatile samples were collected during this study.

\section{Insect behavioural bioassays}

Insect preference to male flowers and female flowers were assayed using $X$ shaped olfactometer; each branch was $100 \mathrm{~cm}$ long (modified from Dufay et al., 2003). On the other hand, insect preference to identified volatile compounds was assayed using $Y$ shaped tube of olfactometer (each branch was $6 \mathrm{~cm}$ long). During this study, we used between 100 and 500 individuals (depending on the number of available insects) for each volatile tested. All procedures were conducted outside the laboratory in order to mimic natural condition.

\section{Insect daily activities}

Daily activities of E. kamerunicus and T. hawaiiensis in the field were observed betweens 06:00 to 17:00 daily during a month. Movement of both species between male and female flowers was recorded by video recorder and measured. Total numbers of insects move between male and female flowers were defined as total number of foraging insects. All observations were carried out during clear day with maximum cloud cover about $50 \%$.

\section{Data analysis}

Data were analyzed by statistic program Statistica 8.0 (Statsoft
Corp.). Prior to analysis, normality of data was tested. Difference on $E$. kamerunicus and $T$. hawaiiensis preference to volatile produced by oil palm was analyzed by t-test analysis. Significant value for test was $\mathrm{P}<0.05$.

\section{RESULTS}

\section{Volatile produced by oil palm flowers}

Volatile samples of both male and female inflorescence in various flowering stages indicated variation of chemical volatile compounds. Palmitic acid, estragole, and 1dodecyne were found at all flowering stage of male flowers, while chloroacetic acid 4-tetra decyl ester, palmitic acid, farnesol, and squalene were found at all flowering stage of female flowers. In addition, estragole and 1-dodecyne was only emitted by male flower (agree with Misztal, 2010), while farnesol and squalene was emitted by female flowers (Table 1 ).

The content of volatile compounds of male inflorescence (Table 2) and female inflorescence (Table 3) were significantly increased along with maturation of flowering stage. During insect behavioural bioassay, we found that E. kamerunicus significantly responsed positively to 1dodecyne and less preferred undecanoid acid and 2nonynoic acid. On the other hand, $T$. hawaiiensis showed positive respond to undecanoic acid and 2-nonynoic acid (Table 4).

\section{Foraging activities of $E$. kamerunicus and $T$. hawaiiensis}

Observations on daily activities of both E. kamerunicus and $T$. hawaiiensis showed that both insects had different foraging activity. E. kamerunicus were active betweens 10:00 to 11:00, while $T$. hawaiiensis reached its peak in two different times, betweens 08:00 to 09:00 and betweens 14:00 to 15:00 (Figure 1).

\section{DISCUSSION}

\section{Volatile produced by oil palm flowers}

The male inflorescence always blooms earlier than female inflorescence. During this period, E. kamerunicus population reached highest peak in male flowers while $T$. hawaiiensis prefer to stay in female flowers. It seems $E$. kamerunicus is attracted to estragole as oil palm simultaneously release this volatile when male flowers bloom.

When male flower starts to wilt, concentration of estragol starts to decline while concentration of farnesol produced by female inflorescence increased. Under this condition, most of $T$. hawaiiensis moved to male flower while part of $E$. kamerunicus moved to female flowers. This result shows that volatile compounds released by 
Table 1. Types of volatile compounds found in male and female inflorescence of oil palm (Elaeis guineensis) in various flowering stages.

\begin{tabular}{cll}
\hline Flowering stage (\%) & Male flower & Female flower \\
\hline & Undecanoic acid & Chloroacetic acid 4-tetra decyl ester \\
& Palmitic acid & Palmitic acid \\
& Estragole & Farnesol \\
& 2-Nonynoic acid & Squalene \\
& 1-dodecyne & \\
& Undecanoic acid & Chloroacetic acid 4-tetra decyl ester \\
& Palmitic acid & Palmitic acid \\
& Estragole & Farnesol \\
& 2-Nonynoic acid & Squalene \\
& 1-dodecyne & Chloroacetic acid 4-tetra decyl ester \\
& Palmitic acid & Palmitic acid \\
& Chloroacetic acid 4-tetra decyl ester & Farnesol \\
& Estragole & Squalene \\
\hline \multirow{3}{*}{75} & 1-dodecyne & Chloroacetic acid 4-tetra decyl ester \\
& Palmitic acid & Palmitic acid \\
& Chloroacetic acid 4-tetra decyl ester & Farnesol \\
& Estragole & Squalene \\
\hline \multirow{2}{*}{100} & 1-dodecyne &
\end{tabular}

Table 2. Type and amount of volatile compounds ( $\mathrm{ng} / 4 \mathrm{~h}$ ) emitted by male inflorescence of oil palm (Elaeis guineensis) in various flowering stages.

\begin{tabular}{cccccc}
\hline Flowering stage (\%) & 2-Nonynoic acid & Palmitic acid & 1-dodecyne & Undecanoic acid & Estragole \\
\hline 25 & 0.807 & 23.785 & - & 2.683 & 24.840 \\
50 & 1.057 & 52.213 & - & 3.677 & 44.050 \\
75 & - & 76.337 & 2.615 & - & 129.095 \\
100 & - & 98 & 11.751 & - & 313.805 \\
\hline
\end{tabular}

Table 3. Type and amount of volatile compounds ( $\mathrm{ng} / 4 \mathrm{~h}$ ) emitted by female inflorescence of oil palm (Elaeis guineensis) in various flowering stages.

\begin{tabular}{cccc}
\hline Flowering stage (\%) & Palmitic acid & Farnesol & Squalene \\
\hline 25 & 0.474 & 12.147 & 6.911 \\
50 & 0.587 & 30.805 & 26.421 \\
75 & 0.694 & 36.217 & 30.792 \\
100 & 0.738 & 96 & 39.678 \\
\hline
\end{tabular}

male and female inflorescence could produce resources partitioning, since both species consume pollen, which in advance create the coexistence between $E$. kamerunicus and $T$. hawaiiensis.

Resources partitioning hold a huge benefit for $E$. guineensis as it may increase pollination success (Rodriguez-Girones and Santamaria, 2010) since both pollinating species had different pollination effectiveness. Previous research found that movement of $E$. kamerunicus to female flowers are responsible for pollination of oil palm as they carry pollen in their body and it helps conceal flowers at back side of inflorescence to received pollen (Putra, unpublished data). On the other hand, $T$. hawaiiensis that lived inside female flower inflorescence may contributed to pollination prior to $E$. kamerunicus movement as this insects is believed to have great ability to detect flowers which are ready to be pollinated (Varatharajan et al., 1982). 


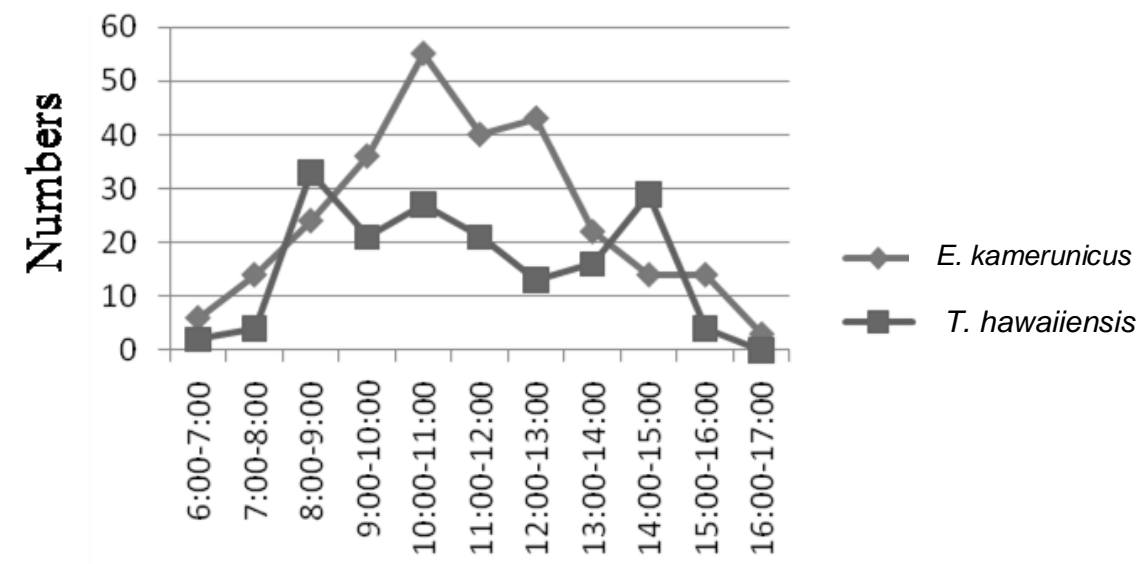

\section{Time of day}

Figure 1. Daily activity of Elaidobius kamerunicus and Thrips hawaiiensis in oil palm flowers.

\section{Foraging activities of $E$. kamerunicus and $T$. hawaiiensis}

Furthermore, we also observed the possibility that both species coexist due to difference in foraging activity.

$E$. kamerunicus used to live in a hot environment in Africa with peak foraging activity between 10:00 am and 01:00 pm (Appiah, 1999). When they were introduced to Indonesia, they need a certain condition to reach their optimum activity; therefore E. kamerunicus preferred to do their activity during midday. On the other hand, $T$. hawaiiensis, which is a native insect and have a relatively soft cuticle, need to avoid direct sun; therefore they preferred to do their activity in the morning and late afternoon when temperature is much lower. This results to raising the possibility that diurnal foraging differences observed in this study arose not from resources competition alone but also by differences in morphological and physiological condition (Hart and Eckhart, 2010).

However, the effect of resource partitioning and foraging behavior separation requires a demonstration of long term population-dynamic consequences (Palmer et al., 2003). Furthermore, it is also important to investigate shorter-term responses, to answer whether $E$. kamerunicus and $T$. hawaiiensis could modify their diurnal activity in response to the variation of resources and abundance of other pollinators (Pleasants, 1981; Thomson et al., 1987; Palmer et al., 2003).

\section{Conclusion}

Both E. kamerunicus and T. hawaiiensis response differently to volatile emitted by oil palm flowers to create a resource partition and different foraging time that enable they to coexist and benefit from pollination of oil palm.

\section{ACKNOWLEDGMENTS}

This study was made possible due to the support of the management in oil palm plantation of Bukit SentangLangkat, North Sumatera-Indonesia. We also thank the assistants for their contribution during the field work.

\section{REFERENCES}

Adaigbe VC, Odebiyi JA, Omoloye AA, Aisagbonhi Cl, lyare O (2011). Host location and ovipositional preference of Elaeidobius kamerunicus on four host palm species. J. Hort. Forest. 3:163-166.

Aisagbonhi $\mathrm{Cl}$, Kamarudin N, Okwuagwu CO, Wahid MB, Jackson $\mathrm{T}$, Adaigbe $V$ (2004). Preliminary observations on a field population of the oil palm-pollinating weevil Elaeidobius kamerunicus in Benin City, Nigeria. Int. J. Trop. Insect Sci. 24:255-259.

Appiah SO (1999). Studies into entomophil pollination of oil palm in Ghana. J. Ghana Sci. Assoc. 1:70-77.

Dufay M, Hossaert M, Marie M, Anstett C (2003). When leaves act like flowers: How dwarf palms attract their pollinators. Ecol. Lett. 6:28-34.

Grinson PL, Bessiere MJ, Hossaert MM (2002). Specific attraction of fig-pollinating wasps: Role of volatile compounds released by tropical figs. J. Chem. Ecol. 28:283-295.

Hart GM, Eckhart VM (2010). Ecological separation in foraging schedule and food type between pollinators of the California wildflower, Clarkia xantiana ssp. Xantiana. J. Poll. Ecol. 2:13-20.

Henderson AA (1986). A review of pollination studies in the Palmae. Bot. Rev. 52:221-259.

Hussein MY, Lajis NH, Kinson A, Teo, CB (1989). Laboratory and field evaluation on the attractancy of Elaeidobius kamerunicus Faust to 4allyanisole. Porim Bull. 18:20-26.

Misztal PK, Owen SM, Guenther AB, Rasmusen R, Geron C, Harley P, Phillips GJ, Ryan A, Edwards DP, Hewitt CN, Nemitz E, Siong J, Heal MR, Cape JN (2010). Large estragole fluxes from oil palm in Borneo. Atm. Chem. Phy. Disc. 10:1517-1557.

Palmer TM, Stanton ML, and Young TP (2003). Competition and coexistence: Exploring mechanisms that restrict and maintain diversity 
within mutualist guilds. Ame. Nat. 162:S63-S79.

Pardede DB (1990a). Indigenous pollinator insects of oil palm at Kertahardja Lebak and Kertajaya estates nucleus estate smallholder project V South Banten. Bul. Perk. 21: 213-223 (In Indonesian with English Abstract).

Pardede DB (1990b). Biologi Elaeidobius camerunicus Faust (Coleoptera:Curculionidae) dalam Hubungannya dengan Penyerbukan Bunga Kelapa sawit. Dissertation. Institut Pertanian Bogor. Bogor (In Indonesian with English Abstract).

Pleasants JM (1981). Bumblebee response to variation in nectar variability. Ecology 62:1648-1661.

Rodriguez-Girones MA, Santamaria L (2010). How foraging behavior and resource partitioning can drive the evolution of flowers and the structure of pollination networks. Open Ecol. J. 3:1-11.

Syed RA (1979). Studies on oil palm pollination by insects. Bull. Entomol. Res. 69:213-224.

Syed RA (1980). Pollinating Insect of Oil Palm 1977-1980. Report Commonwealth Institute of Biological Control. pp.1-107.

Syed RA (1981). Pollinating Thrips of Oil Palm in West Malaysia. Planter 57:61-81.
Syed RA, Law IH, Corley RHV (1982). Insect Pollination of Oil Palm: Introduction, establishment and pollinating efficiency of Elaeidobius kamerunicus in Malaysia. Planter 58:547-561.

Tandon R., Manohara TN, Nijalingappa BHM, K.R. Shivanna KR (2001). Pollination and pollen-pistil interaction in oil palm, Elaeis guineensis. Ann. Bot. 87:831-838.

Thomson JD, Peterson SC, Harder LD (1987). Response of traplining bumble bees to competition experiments: shifts in feeding location and efficiency. Oecologia. 71:295-300.

Varatharajan R, Gopinathan K, and Ananthakrishnan TN (1982). Comparative efficiency of Thrips in relation to other foraging insects in the pollination of Cosmos bipinnatus Cav. (Compositae). Proc. Indian Nat. Sci. Acad. 6:735-739. 